

VOL. XI, 20: 419-431.

BIAEOWIEŻA

15.XII.1966

\author{
Władysław GRODZIŃ SKI, Andrzej GÓRE C K I, \\ Kazimiera JANAS \& Paweł MigULA
}

\section{Efiect of Rodents on the Primary Productivity of Alpine Meadows in Bieszczady Mountains}

\author{
[With 2 Tables \& 2 Figs.]
}

\begin{abstract}
The distribution, abundance and density of small rodents was studied in the alpine meadows of the polish Bieszczady Mountains (Eastern Carpathians). The energy flow through the population of rodents was estimated in this ecosystem. The alpine meadows ("połonina's") have an autonomous community of small rodents. The voles (Pitymys subterraneus and Microtus agrestis) are dominating, other meadow rodents (Sicista betulina, Apodemus agrarius, Arvicola terrestis) occur only sporadically while the forest rodents (Apodemus flavicollis, Clethrionomys glareolus) may occasionally feed in alpine meadows. The distribution of rodents in the alpine meadows is uneven; in the dwarf shrubs (scrub) they are four times as abundant as in the open meadows. The estimated mean rodent density on grass alpine meadows was 15 per hectare (13 P. subterraneus and $2 \mathrm{M}$. agrestis). The energy flow through these populations of $P$. subterraneus and $M$. agrestis amounts to $61,012 \mathrm{Kcal} / \mathrm{ha} / \mathrm{year}$. Of this, the cost of maintenance is 60 thousand $\mathrm{Kcal}$ and the net production is only one thousand Kcal. The annual food consumption of these rodents is over $76,000 \mathrm{Kcal} / \mathrm{ha}$. This corresponds to $20 \mathrm{~kg}$ of dry hay which was eaten from every hectare. However, the influence of rodents on the alpine meadows vegetation is negligible, as they are consuming only $1.03 \%$ of the annual primary productivity.
\end{abstract}

\section{INTRODUCTION}

In the polish part of the Bieszczady Mountains (Eastern Carpathian Mits.) the alpine meadows ("polonina's") cover the area of nearly 3,300 ha ( $=8,150$ acress). They comprise the massif of Tarnica ( $1348 \mathrm{~m}$. above sea level) - Krzemien $(1335 \mathrm{~m}$.) and Halicz $(1335 \mathrm{~m}$.); the total of about 2,000 ha, the ridges of Polonina Caryńska $(1297 \mathrm{~m}$.$) and Połonina Wetlińska (1235 \mathrm{~m}$.$) ; the total of about 1,100 \mathrm{ha}$; and the shoulder of Rawka $1303 \mathrm{~m}$. ( $\left(49^{\circ} 2^{\prime}-49^{\circ} 12^{\prime} \mathrm{N}\right.$ and $\left.\lambda 22^{\circ} 28^{\prime}-22^{\circ} 49^{\prime} \mathrm{E}\right)$. The zone of alpine meadows is above the upper timberline i.e. beginning at rougly $1,150 \mathrm{~m}$. above sea level, and reaching the highest peaks. Below the timber line is the beech forest 
(Fagetum carpaticum) the upper zone of spruce forests is absent in the Bieszczady Mts. ( $\mathrm{Z}$ a z z cki, 1964). Consequently, the timber line is relatively low and the zone of alpine meadows is very vast. On the alpine meadows three plant communities are dominating; grass meadows (Calamagrostis arundinacea community and Pöeto-Deschampsietum association) and the bilberry associations (Vaccinium myrtilli, Emperto-hermaphroditi vaccinietum). There are also compact growths of dwarf alder (Alnus viridis) and small aggregations of dwarf sorb (Sorbus aucuparia var. glabrata) as well as small rock communities (Pałczyński, 1962; Z arzy c ki, 1964).

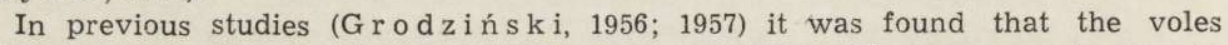
(Microtus agrestis and Pitymys subterraneus) and shrews (Sorex araneus) occur in the alpine meadows in Bieszczady Mts. The purpose of the present investigation was to study the distribution, abundance and density of the population of small rodents in some detail, and to estimate the energy flow through these populations.

\section{MATERIALS AND METHODS}

The small rodents were collected over a period of four years $(1961,62,64$ and 65) during 10-15 day field trips in August and September. The methods of trap-night, trap-line and the intensive removal on large plot (so called "Standard-

Table 1.

The material of small mammals collected in the alpine meadows of Bieszczady Mts. using three methods of trapping.

\begin{tabular}{|c|c|c|c|c|c|}
\hline Species of small mammal & 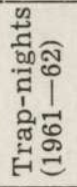 & 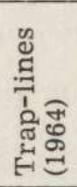 & 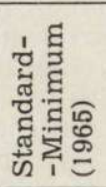 & Sum & $\begin{array}{l}\text { Per } \\
\text { cent }\end{array}$ \\
\hline Sorex araneus (Lin n a u s, 1758) & 9 & 24 & 15 & 48 & 21.4 \\
\hline Sorex minutus (L i n n a e us, 1766) & - & 2 & $=1$ & 3 & 1,3 \\
\hline Sorex alpinus (Schin z, 1837) & - & 1 & - & 1 & 0.4 \\
\hline Sicista betulina (P a 11 as, 1788) & 1 & - & 2 & 3 & 1.3 \\
\hline Mus musculus (Linna e us, 1758) & - & - & 1 & 1 & 0.4 \\
\hline Apodemus agrarius (P a 11 as, 1771) & 一 & - & 1 & 1 & 0.4 \\
\hline Apodemus flavicollis (M elchior, 1834) & - & 一 & 33 & 33 & 14.7 \\
\hline Clethrionomys glareolus (S c hre be r, 1780) & 一 & 3 & 4 & 7 & 3.1 \\
\hline Arvicola terrestris sherman ( $\mathrm{S} h$ a w, 1801) & 1 & - & - & 1 & 0.4 \\
\hline Pitymys subterraneus & & & & & \\
\hline (de Sélys-Longchamps, 1835) & 17 & 41 & 54 & 112 & 49.8 \\
\hline Microtus agrestis ( $\mathrm{Linnaeus,} \mathrm{1761)}$ & 10 & 1 & 4 & 15 & 6.8 \\
\hline Totaly & 38 & 72 & 115 & \multicolumn{2}{|c|}{$225=100.0 \%$} \\
\hline
\end{tabular}

-Minimum") were used during subsequent trips. All animals were caught with snap-traps, with the cotton wick fried in oil with flower, fresh carrot or bacon used as a bait.

The method of trap-nights was used in several places on Połonina Caryńska, 
Połonina Wetlińska and Mała Rawka. The traps were placed in groups of 10 to 20; their location changed every day. A total of 620 trap-nights was set. The trap-lines were placed in the regions of Krzemien and Tarnica, predominantly in open meadows but also in the growths of dwarf shrubs (scrub) and on the timberline. Each line was $250 \mathrm{~m}$. long and composed of 50 traps placed every $5 \mathrm{~m}$. The total of 10 trap-lines was used. Each line was open during a period of 5 to 12 days.

The trapping with the "Standard-Minimum" method (Grodziński et al., 1966) was carried out on a square $240 \times 240 \mathrm{~m}$. plot ( $5.76 \mathrm{ha}=14.2$ acress) located on the southern slopes of the Krzemien Mt. The plot was covering typical Pöeto-Deschampsietum and Calamagrostietum communities. The trapping lasted 12 days, with 6 days of prebaiting and 6 of heavy trapping. The plot was composed of 16 rows with 16 points spaced $15 \mathrm{~m}$. from each other. In each of these 256 points the rodents were prebaited with some oats on a piece of cardboard. The consuming of oats was controlled daily. On the sixth day the oats were removed and on every point two snap-traps were set $(2 \times 256=512$ traps). The trapping lasted for the subsequent six days. During this period the traps were checked every morning and evening.

Using these three methods a total of 225 small mammals was collected on the alpine meadows, including 173 specimens of rodents (Table 1). The stomach contents of some of these rodents were later examined determining both the food components and their amount by volume (D r o ż d ż, 1966).

\section{RESULTS}

\section{Small Rodent Community}

Among the small mammals collected in the alpine meadows were 8 species of rodents and 3 species of shrews. Rodents were making up roughly $3 / 4$ of all trapped mammals (Table 1 ). The pine vole (Pitymys subterraneus) definitely was the most numerous in the small rodent community dominating in the samples during the four year period $(64.7 \%)$. The next most frequently occuring species were the field voles (Microtus agrestis - $8.7 \%$ of the rodents) and, in one year, the yellownecked field mouse (Apodemus flavicollis - 19.1\% of the rodents). The abundance of the birch mouse (Sicista betulina) is probably well above the value indicated by trapping $(1.7 \%$ of the rodents). S. betulina were seen frequently in the meadows in the area of Krzemien, Tarnica and Połonina Wetlińska, but they were caught in snap-traps only sporadically. The general composition of the rodent communities was similar in different alpine meadows and in different years, although in $1961-62 \mathrm{M}$. agrestis was probably more abundant, and in 1965 there were many A. flavicollis.

The described rodent community is heterogeneous; "meadow rodents" are dominating but "forest rodents" are also present. The "meadow rodents" category includes the species living in the forest meadows: $P$. subterraneus, $M$. agrestis, $A$. terrestis, and with certain reservations $S$. betulina as well as the species living in the fields: $A$. agrarius and $M$. 
musculus. Apodemus flavicollis and C. glareolus are typically "forest" species. Seventy seven per cent of the captured rodents were from the meadow category, while $23 \%$ were forest rodents. However, all forest rodents were captured close to the forest. In 1964 all C. glareolus were captured in the upper timberline of the beech forest and in 1965, very close to this forest. The majority of A. flavicollis was captured in 1965 in the lower rows of our plot which was located only $100 \mathrm{~m}$. above the timberline. Besides, the invasion of $A$. flavicollis in the alpine meadows in 1965 can be explained by the increased density of these mice in Fagetum carpaticum forest. The marked growth of the A. flavicollis population in 1965 followed the heavy fall of beechmast in the autumn of the preceding year. On the other hand, some meadow rodents penetrate the adjoining upper part of the forest. Both $P$. subterraneus and $M$. agrestis were occasionally captured in the small forest meadows close to the timberline and some $P$. subterraneus were caught in the forest itself.

The degree of the association of different rodents with the alpine meadow or the beech forest zone is well represented by the food habits of these animals. The stomach contents of $20 \mathrm{P}$. subterraneus and $20 \mathrm{~A}$. flavicollis captured in 1965 on alpine meadows were analysed. The food of $P$. subterraneus was composed of meadow plants ( $90.5 \%$ by volume) and insects $(9.5 \%)$. The plant food consisted of greens $(58.4 \%)$, seeds $(18.4 \%)$ bilberries (Vaccinium - $3.7 \%)$ and roots $(10.0 \%)$. The A. flavicollis was consuming predominantly plant food (nearly $94 \%$ ) and some animal food. Over half of the plant food $(50.0 \%$ of the total) must have came from the beech forest. Beechmast amounted to $33.5 \%$ and green parts of predominantly dicotyledonous plants to $16.5 \%$. Only three mice were found without beechmast in the stomach contents. In the alpine meadows the mice were consuming grass seeds ( $27 \%$ by volume) and green parts of grass $(4.0 \%)$ as well as the berries of Vaccinium $(11.0 \%)$. These findings indicate that $P$. subterraneus is a typical inhabitant of alpine meadows while the majority of $A$. flavicollis leaves the forest only to feed in the meadows.

Consequently, the alpine meadows have an autonomous and very specific small rodent community. The P. subterraneus is definitely dominating, $M$. agrestis and $S$. betulina are less common. Other meadow and field rodents (A. terrestris, A. agrarius and $M$. musculus) occur in this community only sporadically. The forest rodents can be found in the alpine meadows only periodically.

\section{Distribution of Small Rodents}

The results of trapping with trap-lines and trap-nights indicate, that the distribution of small mammals in alpine meadows is uneven. It concerns both the relative abundance and, to a smaller degree, the 
species composition. The relative abundance can be measured by either the mean number of animals captured per one trap-line (average number per line), or the number captured during 100 trap-nights (so called \% of trap success).

The areas of alpine meadows subject to trapping can be divided into three types of habitat according to the plant cover: open alpine meadows, growths of dwarf shrubs (scrub) in the meadows and the zone of upper timberline. The mean number of rodents per line is low in open meadows (2.3), very high in the scrub (10.5) and intermediate in the timberline (4.1). The number of small mammals (rodents and shrews) per one line was in these three habitats $2.9,15.0$ and 5.8, respectively. Converting the data from trap-lines into per cent of trap success and adding the results from trap-nights results in the total value of $1.2 \%$ for the open meadows, $4.5 \%$ for the growths of shrubs and $2.6 \%$ for the timberline zone. Somewhat higher values for the open meadows were obtained on the "Standard-Minimum" plot, where every row of traps (32 traps $-240 \mathrm{~m})$ can be considered as a trap-line. The average of 4.0 meadow rodents (4.9 rodents and shrews) was captured per one such trap line; the corresponding per cent values are 2.1 and $2.5 \%$. These comparisons indicate that the relative abundance of rodents in the open alpine meadows is roughly four times lower than in the growths of shrubs. Consequently the dwarf shrubs in the alpine meadows appear to be a "preserve" for the small rodents.

In the open alpine meadows small mammals were trapped in different plant communities. The relative abundance was usually higher in the grassy communities (Pöeto-Deschampsietum and Calamagrostietum average $1.8 \%$ ) than in Vaccinium myrtilli and Empetro-Vaccinietum (average $0.7 \%$ ). P. subterraneus were captured predominantly in these regions, while $M$. agrestis were much less frequent. Shrews were very few, except for the Vaccinietum. In the growths of dwarf alder (Alnus viridis) the relative abundance of rodents was slightly higher $(4.8 \%)$ than in the aggregations of the dwarf sorb (Sorbus aucuparia var. glabrata $3.6 \%)$. In the scrub almost exclusively $P$. subterraneus and Sorex were captured, shrews often amounting to as much as one third of the total. The zone of timberline had an intermediate abundance of rodents, with the result of a rather high abundance in the forest itself (C. glareolus, A. flavicollis, Sorex - $4.2 \%)$, somewhat lower abundance in the forest meadows close to the edge of the forest ( $P$. subterraneus, Sore $x-2.4 \%$ ) and the very low abundance at the edge of the forest (Sorex $-0.6 \%$ ).

\section{The Density of Small Rodents}

The density of small rodents in the alpine meadows was estimated from the Standard Minimum trapping on the plot of 5.76 ha. The history of 
trapping is given in the Fig. 1. During the period of prebaiting the per cent of points with partially consumed oats was increasing gradually from 7.4 to 61.7 per cent. In the following period of removal the number of small mammals captured in subsequent days was 41, 19, 24, 10, 9 and 12. From these, rodents amounted to 39, 15, 20, 8, 9 and 8, respectively. The rate of capturing was considerably higher for meadow than for forest rodents. The curve of captures of alpine meadow rodents (mainly $P$. subterraneus; also $M$. agrestis, S. betulina, A. agrarius and M. musculus) was falling sharply in subsequent days, while the curve of
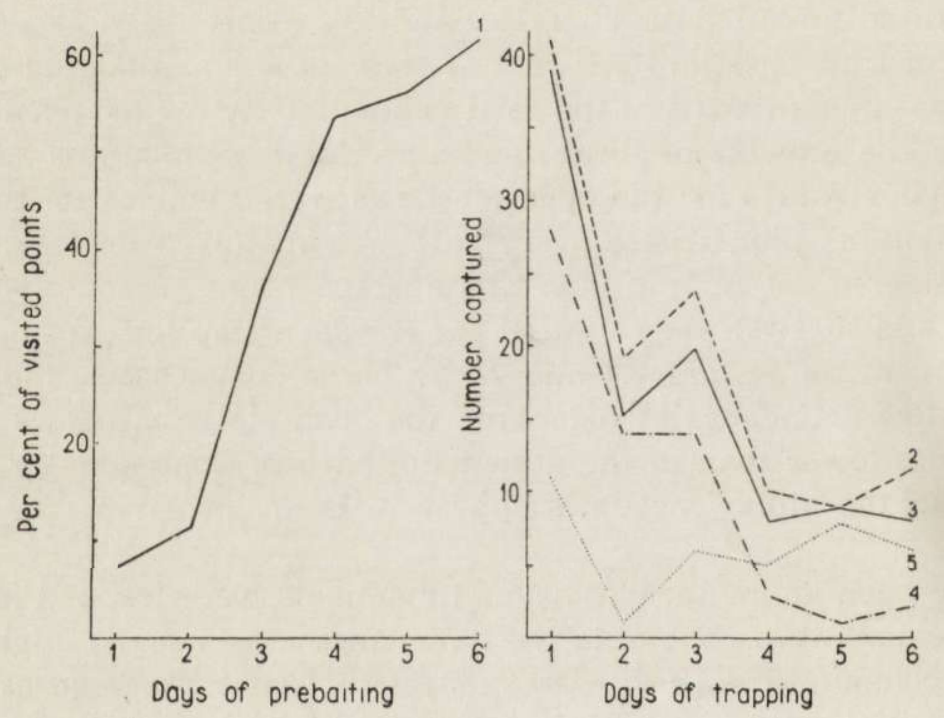

Fig. 1. The course (history) of "Standard-Minimum" trapping in the alpine meadows (5.76 ha plot).

On the left - the period of prebaiting; on the right - the period of intensive trapping. 1 - per cent of prebaiting points visited by rodents, 2 - the number of captured small mammals (rodents and shrews). 3 - the total number of rodents, 4 - the number of meadow rodents, 5 - the number of forest rodents.

trapping of the forest rodents (mainly A. flavicollis; also C. glareolus) was falling only during the first two days and then returned to the relatively high level (Fig. 1). The difference is even more pronounced when the rate of captures is expressed in cumulative per cent, considering the sum captured during 6 days as $100 \%$ (Fig. 2). During the first three days of trapping $92.6 \%$ of all $P$. subterraneus were captured, while the corresponding value for $A$. flavicollis was only $45.4 \%$. Consequently, in calculating the density these two groups of rodents were treated separately.

The density of rodents was estimated by plotting the number of individuals captured every day against the cumulative captures of individ- 
uals. The calculation were based on the linear regression equation $y=$ $=a x+b$, in which $b$ is the point where the regression line croses the ordinate and $a$ is the tangent of the angle $(180-\alpha)$ between the regression

- line and the abscissa (Grodziński et al., 1966). The regression line for the meadow rodents was based on the four points corresponding to the first four days of trapping, and for the forest rodents - on three

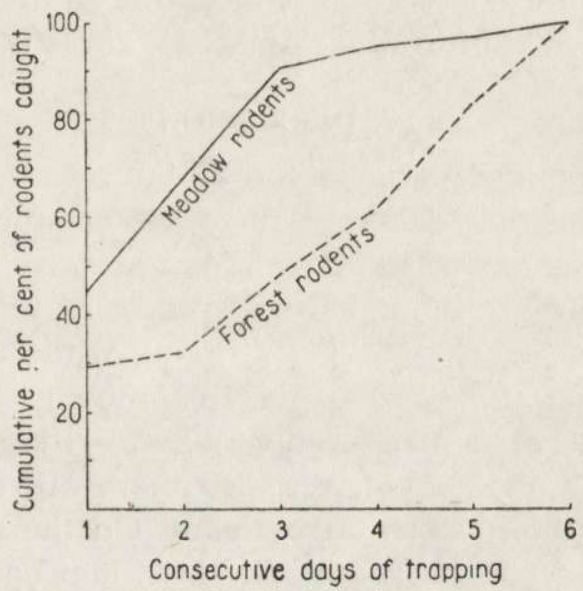

Fig. 2. The comparison of the rate of trapping the "meadow" rodents ( $P$. subterraneus and others) and the "forest" rodents (A. flavicollis and C. glareolus) on the "Standard-Minimum" plot.

Table 2.

The estimation of the density of rodents on alpine meadows.

The number of animals was computed from the trapping on 5.76 ha plot using the regression equation (for details cf. text p. 421).

\begin{tabular}{|c|c|c|c|c|}
\hline \multirow[t]{2}{*}{ Group of rodents } & \multirow{2}{*}{$\begin{array}{c}\text { Total } \\
\text { captured } \\
\text { in } 6 \text { days }\end{array}$} & \multirow{2}{*}{$\begin{array}{l}\text { Equation of } \\
\text { regression } \\
y=a x+b\end{array}$} & \multicolumn{2}{|c|}{$\begin{array}{l}\text { Number of rodents esti- } \\
\text { mated from regression }\end{array}$} \\
\hline & & & No. per plot & No. per ha \\
\hline All rodents ${ }^{1}$ ) & 99 & $0.397 x+37.1$ & 93.4 & 16.2 \\
\hline Meadow rodents ${ }^{1}$ ) & 62 & $0.414 x+27.8$ & 67.1 & 11.7 \\
\hline P. subterraneus $\left.{ }^{1}\right)$ & 54 & $0.454 x+26.3$ & 57.9 & 10.1 \\
\hline Forest rodents ${ }^{2}$ ) & 37 & $0.439 x+9.3$ & 21.2 & 3.7 \\
\hline A. flavicollis ${ }^{2}$ ) & 33 & $0.539 x+8.7$ & 14.8 & 2.7 \\
\hline
\end{tabular}

1) Linear regression for the first 4 days of trapping. ${ }^{2}$ ) Linear regression for the first 3 days of trapping.

such points (Tab. 2). The estimated number of rodents on the whole plot is represented by the point where the regression line crosses the abscissa, i.e. the plot of cumulative captures. The overall density of rodents in the alpine meadows is rather low - the mean of 16 animals per hectare. Of these, 12 were meadow rodents (including 10.1 of $P$. subterraneus per ha) and almost 4 consisted of forest rodents, including 2.7 of A. flavicollis 
per ha (Tab. 2). However, this estimation has to be slightly corrected, considering that during the studied year A. flavicollis was only an occasional visitor in the meadows. It seems worth indicating that the relative abundance of rodents in open meadows was nearly four times lower than in the growths of shrubs which are covering nearly one tenth of the alpine meadows in Bieszczady Mts. Consequently, the overall density of rodents in the grass alpine meadows can be estimated as about 15/ha, including $13 P$. subterraneus and $2 M$. agrestis.

\section{DISCUSSION}

The rodent community found in the alpine meadows in Western Bieszczady Mis. is somewhat different from the communities found in the meadows in other regions of the Carpathian Mts. (Grodziński, 1957). In the alpine meadows of the Eastern Carpathians the dominating rodent species is usually $M$. arvalis ( $\mathrm{Pa} 11 \mathrm{a} \mathrm{s}, 1779$ ), while $P$. subterraneus and $M$. agrestis are less numerous and usually inhabit the zone of dwarf mountain pine and alder (Pinus mughus and Alnus viridis) (T a t a rinov, 1956; Turjanin, 1956). Besides there are differences between different ranges of the Eastern Carpathians. On the Połonina Borżawska which is located close to the Bieszczady Mts. and has the same zones of vegetation, the most abundant rodents were $M$. arvalis and $M$. agrestis (S tra utman \& Benedjuk, 1954; Rudyšyn, 1961). However, in the Czarnohora Mts. alpine meadows $M$. arvalis was dominating and $M$. agrestis was very rare ( $\mathrm{S}$ a g a $\mathrm{n}, 1939$; $\mathrm{R}$ u d y šy $\mathrm{n}, 1961)$. In the Polish Western Carpathians P. subterraneus is a typical inhabitant of forest meadows and clearings, and above the timberline it occurs mostly in the zone of Pinus mughus (Grodziński, 1959; Kowalski, 1960). The relatively low density of rodents seems to be the common feature of many alpine meadows in the Carpathians.

To estimate the effect of rodents on the vegetation of alpine meadows in the Bieszczady Mts., the energy flow through the population of two dominating voles ( $P$. subterraneus and $M$. agrestis) was calculated. The equation developed specially for rodents by Golley (1962) was used. This equation was slightly modified and simplified because of the very low accuracy of these estimations:

$$
A_{T}=\sum(R \bar{B})_{T}+K_{b}(\bar{B} \Theta)
$$

The corresponding values were the following: $\overline{\mathrm{B}}-$ mean population biomass i.e. average numbers $(\mathrm{N})$ per 1 ha $\times$ mean body weight of an individual. The mean number of rodents per 1 ha was established as 13 $P$. subterraneus and $2 \mathrm{M}$. agrestis. The mean body weight was $14 \mathrm{~g}$ for $P$. subterraneus and $22 \mathrm{~g}$ for $M$. agrestis. This weight is reached by 
animals 2 to 4 months old (W a silew ski, 1956; 1960). The biomass of the population of these two voles calculated in the way described above was $226 \mathrm{~g} / \mathrm{ha}$.

$\Theta$ - turn-over rate in the population of voles expressed as the multiple of average life span within one year. W a silew ski (1960) reported, that in the natural population of $P$. subterraneus the life span of the majority of individuals was up to 4 months. The full life-table of $M$. agrestis was computed by Leslie \& Ranson (1940), the mean life span was also 4 months. Consequently, it was assumed for both voles that the mean life span is 4 months and the turn-over is 3 per year.

$\mathrm{K}_{\mathrm{b}}$ - the caloric value of the body in small rodents. The value of $1.468 \mathrm{Kcal} / \mathrm{g}$ of fresh weight was used. This value was determined for another vole species (M. arvalis) (G ó r e c k i, 1965).

$\mathrm{R}$ - is the daily metabolic rate in $\mathrm{Kcal} / \mathrm{g} /$ day. The average daily metabolic rate $(A D M R)$ of $P$. subterraneus was thoroughly studied by $\mathrm{Grębczynski}(1964)$. At $+20^{\circ} \mathrm{C}$ the $A D M R$ was $5.61 \mathrm{ccm} \mathrm{O}_{2} / \mathrm{g} / \mathrm{hr}$ and at $+5^{\circ} \mathrm{C}-8.44 \mathrm{ccm} \mathrm{O}_{2} / \mathrm{g} / \mathrm{hr}$. The daily energy budget of $P$. subterraneus was estimated considering the seasonal changes in chemical thermoregulation and in the daily pattern of activity in these species (S mirnov, 1962) as well as the climatic conditions of the Bieszczady Mts. (G r o$\mathrm{d} z$ iński, 1957; Pa łczyński, 1962). For the animals weighing $14 \mathrm{~g}$ this estimation resulted in the value of $9.94 \mathrm{Kcal} /$ day in the summer and $11.23 \mathrm{Kcal} /$ day in the winter $(0.710$ and $0.802 \mathrm{Kcal} / \mathrm{g} /$ day, respectively; annual mean $-0.756 \mathrm{Kcal} / \mathrm{g} /$ day). Analogous model of the daily energy budget of $M$. agrestis was based on the value of resting metabolic rate $(R M R)$ - which is $4.669 \mathrm{ccm} \mathrm{O}_{2} / \mathrm{g} / \mathrm{hr}$. at $20^{\circ} \mathrm{C}(\mathrm{Grodz}$ ińs ki, 1961). The daily energy budget of $M$. agrestis (body weight $-22 \mathrm{~g}$ ) was calculated considering both the diurnal pattern of activity of this vole (Erkinaro, 1961; Grodziński, 1962) as well as the intensity of heat production computed for other voles (S m irnov, 1962). The result was $12.94 \mathrm{Kcal} /$ day in the summer and $13.90 \mathrm{Kcal} /$ day in the winter $(0.588$ and $0.632 \mathrm{Kcal} / \mathrm{g} /$ day, respectively; annual mean -0.610 $\mathrm{Kcal} / \mathrm{g} /$ day).

$\mathrm{T}$ - the period of time; one year i.e. 365 days.

The total energy flow through the population of $P$. subterraneus and $M$. agrestis calculated from the above data amounts to $61,012 \mathrm{Kcal} /$ ihectare/year. Of this considerable amount of energy the cost of maintenance (= respiration) equals $60,017 \mathrm{Kcal}$ and the net production i.e. production of the body of rodents - only $955 \mathrm{Kcal}$. The energy flow is slightly smaller than the food intake of voles as it corresponds only to the value of assimilated food. The digestibility of bulk food of Microtus pennsylvanicus (Ord, 1815) amounts to $82 \%$ (Golle y, 1960) and both 
P. subterraneus and M. agrestis are consuming predominantly bulk food (greens). Assuming the digestibility of their natural food in the alpine meadows as $80 \%$, the yearly food intake can be estimated for 76,265 $\mathrm{Kcal} / \mathrm{ha}$. This corresponds to over $20 \mathrm{~kg}$ od dry hay eaten by rodents in every hectare of the alpine meadows.

The net primary productivity of alpine meadows is not very high. The crop of hay from the Calamagrostis community is 500 to $1,000 \mathrm{~kg} / \mathrm{ha}$ when the grass is cut and 1,000 to $1,200 \mathrm{~kg} / \mathrm{ha}$ with intensive grazing. The crop from the Pöeto-Deschampsietum meadow is higher and amounts to $2,500-3,000 \mathrm{~kg}$ of hay/ha ( $\mathrm{Zab}$ ock $\mathrm{i}, 1939 ; \mathrm{P}$ a ł c zy ńs k i, 1962). The mean production of the above-ground parts of plants in these two associations is probably about $2,000 \mathrm{~kg}$, or $7.4 \mathrm{million} \mathrm{Kcal} / \mathrm{ha} /$ year.

The prevailing majority of this primary production of the alpine meadow can be the potential food of rodents (Stra utman \& Bene$\mathrm{djuk}, 1954)$. Both $P$. subterraneus and $M$. agrestis are polifagous herbivores. The natural food of $P$. subterraneus in the Sorbeto-Piceetum forest in the Tatra Mts. is composed predominantly $(69 \%)$ from the vegetative parts of plants. In the stomach contens of these rodents the leaves and stems are prevailing, the roots are less frequent and the berries, flowers and moss correspond to about $25 \%$ (H o li š o v a, 1965). The analysis of stomach contents of $P$. subterraneus from Bieszczady alpine meadows revealed similar dominance of vegetative parts of plants (greens and rcots) $-68.4 \%$ by volume. These calculations indicate that from the great abundance of available food the voles are consuming only one per cent of the total production of alpine meadows (food consumption - 76,265 Kcal/ha in relation to the primary net productivity - 7,400,000 Kcal/ha, equals $1.03 \%$ ). In fact the food consumption may be even less as the voles are eating some underground parts of plants and some animal food. However, the effect of the rodents on the alpine meadows vegetation is most likely greater than indicated by the calculated consumption. The voles tend to destroy some of the consumed plants and leave many parts uneaten (K u č e r u k, 1963). Nevertheless, the total effect of rodents on the productivity of alpine meadows is negligible. This is due to relatively low density of rodents in the Bieszczady Mts., similarly to other regions of the Carpathian Mts. Assuming that the grass communities occupy 2,000 ha from the total of 3,300 ha of Bieszczady alpine meadows, it can be calculated that the rodents consume over 42 tons of hay in this area.

Acknowledgements: Considerable part of the small mammals was collected by the students of the Jagiellonian University, Cracow, during two field trips to the Bieszczady Mts. Two of these are the junior-authors of this paper (K. J. and P. M.). We would like to express our sincere thanks for the help in the field and in the laboratory to several others: B. B obek, S. B or on, M. Brzycka, M. Firszt, F. Kaczmarski, W. Kania, W. Kochan, M. Eepkowska, A. Malaz- 
drewicz, A. Tryhubczak, M. Wieloch, A. Wierzbicka and Z. Woś. We are also most grateful to Professor W. S kur a towi cz, Poznań, for critical reading of the manuscript and to $\mathrm{Dr}$. J. R a czyński, Białowieża, for the identification of the atypicall skull of $P$. subterraneus.

\section{REFERENCES}

1. D ro $\dot{z} d \dot{z}$ A., 1966: Food habits and food supply of rodents in the beech forest. Acta theriol., 11, 15: 363-384.

2. Erkinaro E., 1961: The seasonal change of the activity of Microtus agrestis. Oikos, 12, 1: 157-163.

3. G ę b c z y ński M., 1964: Effect of light and temperature on the 24-hour rhythm in Pitymys subterraneus (de Sél. - Long.). Acta theriol., 9, 9: 125-137.

4. Golley F. B., 1960: Energy dynamics of a food chain of an old-field community. Ecol. Monogr., 30, 2: 187-206.

5. Golle y F. B., 1962: Mammals of Georgia - a study of their distribution and functional role in the ecosystem. Univ. Georgia Press : 1-218. Athens.

6. Górecki A., 1965: Energy values of body in small mammals. Acta theriol., 10, 23: 333-352.

7. Grodziński W., 1956: Swiat roślin i zwierząt w Bieszczadach Polskich. Wierchy, 25: 168-176.

8. Grodziński W., 1957: Materials for the study of the vertebrate fauna of the Western Bieszczads. Zesz. Nauk. UJ. Zool., 1: 177-221. Kraków (In Polish with English summ.).

9. Grodziński W., 1959: The succesion of small mammal communities on an overgrown clearing and landslip mountain in the Biskid Sredni (Western Carpathians). Ekol. pol., ser. A 7, 4: 83-143.

10. Grodziński W., 1961: Metabolism rate and bioenergetics of small rodents from the deciduous forest. Bull. Acad. Pol. Sci., Cl. II. 9, 12: 493-499.

11. Grodziński W.: 1962: Influence of food upon the diurnal activity of small rodents. Symp. theriol.: 134-140. Praha.

12. Grodziński W., Pucek Z. \& Ryszkowski L., 1966: Estimation of rodent numbers by means of the prebaiting and intensive removal. Acta theriol., 11, 10: 297-314.

13. Holišova V., 1965: The food of Pitymys subterraneus and P. tatricus (Rodentia, Microtidae) in the mountain zone of the Sorbeto-Piceetum. Zool. listy, 14, 1: 15-28. Brno.

14. Kowalski K., 1960: Pitymys M c. Mutrie, 1831 (Microtidae, Rodentia) in the Northern Carpathians. Acta theriol., 4, 6: 81-91.

15. Leslie P. H. \& R anson R. M., 1940: The mortality, fertility and rate of natural increase of the vole Microtus agrestis as observed in the laboratory. J. Anim. Ecol., 9: 27-52.

16. Pałczyński A., 1962: Meadows and pastures in the West Bieszczady Mountains, a geobotanic-economical study. Roczn. Nauk Roln., 99 D: 4-129. (In Polish with English summ.).

17. Rudy šyn M. P., 1961: Rozmiščennja myšovydnyh gryzuniv u roslynnih asociacijah Boržavs'kyh Polonyn i Čarnogory. Nauk. Zap. Muzeju AN URSR., 9: $80-91$. Kyïv. 
18. Sa gan L., 1939: Contribution à la connaissance des Rongeurs de la Czarnohora. Rozpr. i Spraw. I.B.L., A., 42: 48-54. Warszawa. (In Polish with French summ.).

19. Smirnov P. K., 1962: Nekotorye ekologo-fiziologičeskie osobennosti evropejskoj zemljanoj polevki. Vestnik Leningr. Univ., 21, 4: 72-85.

20. Strautman F. I. \& Benedjuk G. O., 1954: Pro posyrenist' myšovydnyh gryzuniv v roslynnyh asociacijah Boržavs'kyh Polonyny. Praci In-tu Agrobiol. AN URSR., 5: 91-112. Kyïv.

21. Tat a rinov K. A., 1956: Zviri zachidnyh oblastej Ukraïny. Vyd. AN URSR: 1-188. Kyïv.

22. Turjanin I. I., 1956: Ekologofaunističeskij obzor podsemejstva polevok (Mammalia, Microtinae) Zakarpatskoj Oblasti. Nauč. Zap. Užgorod. Univ., 21: $81-91$. Užgorod.

23. Wasilewski W., 1956: Untersuchungen über die morphologische Veränderlichkeit der Erdmaus (Microtus agrestis Linne). Ann. Univ. M. Curie-Skłodowska, C 9, 6: 261-305.

24. Wasilewski W., 1960: Angaben zur Biologie und Morphologie der Kurzohrmaus Pitymys subterraneus (de Sélys-Longchamps, 1835). Acta theriol., 4, 12: 185-247.

25. Z a blocki J., 1939: Gospodarka połoninowa w Gorganach Wschodnich i prace nad jej podźwignięciem. Przyroda i Technika, 18, 1: 1-7.

26. Zarzycki K., 1964: The forests of the Western Bieszczady Mts. (Polish Eastern Carpathians). Acta Agraria et Silvestria 3: 3-132 (In Polish with English summ.).

In proof added:

27. K u č e r u k V. V., 1963: Vosdeistve travojadnyh mlekopitajuščih na produktivnost' travostoja stepi $\mathrm{i}$ ih značenie $\mathrm{v}$ obrazovanii organičeskoj časti stepnyh počv. Tr. Mosk. Obšč. Isp. Prir., 10: 157-191.

Keceived, 29 April, 1966.

Department of Animal Genetics and Organic Evolution,

Jagiellonian University,

Kraków 2, Krupnicza 50, Poland.

Władysław GRODZIŃSKI, Andrzej GORECKI, Kazimiera JANAS \& Paweł MIGULA

\section{WPEYW GRYZONI NA PRODUKTYWNOSĆ PIERWOTNĄ POEONIN \\ W BIESZCZADACH ZACHODNICH}

\section{Streszczenie}

W czterech latach badano rozmieszczenie i liczebność, a tałże zagęszczenie drobnych gryzoni na rozległych połoninach w polskich Bieszczadach Zachodnich. Oszacowano również przepływ energii przez populacje gryzoni w tym ekosystemie. Posługiwano się kolejno trzema metodami odłowów: tzw. pułapko-dni, pułapko-linii oraz zanęcania i intensywnego wyłowu na dużej działce (Tabela 1). 
Połoniny posiadają autonomiczny zespół drobnych gryzoni, w którym pod względem liczebności dominują darniówki, Pitymys subterraneus (de Sélys-Longchamps, 1835) i w mniejszym stopniu polniki bure, Microtus agrestis (Linnae us, 1761). Inne gryzonie ląkowe i polne [Sicista betulina ( $\mathrm{Pa}$ ll a s, 1778), Apodemus agrarius (Pallas, 1771) i Arvicola terrestris scherman (S ha w, 1801)] występują sporadycznie, natomiast gryzonie leśne [Apodemus flavicollis (M e l c hior, 1834), Clethrionomys glareolus ( $\mathrm{S} \mathrm{chreber}, 1780$ )] wychodzą z lasu na połoniny tylko w poszukiwaniu pokarmu. Rozmieszczenie gryzoni na połoninach jest nierównomierne, w zwartych zaroślach olchy kosej (Alnus viridis) są one czterokrotnie liczniejsze niż na połoninach otwartych (łąki Pöeto-Deschampsietum i zbiorowisko Calamagrostis arundinacea). Przeciętne zagęszczenie gryzoni na łąkach połoniny oceniono na około 15/hektar, wliczając w tę liczbę 13 darniówek i 2 polniki (Tabela 2, Fig. 1 i 2).

Przepływ energii przez takie populacje darniówek i polników osiąga na połoninie $61.012 \mathrm{kcal} / \mathrm{ha} / \mathrm{rok}$. Z tego na tzw. koszty utrzymania (respiracja) przypada 60 tys. kcal, a na produkcję netto ciała gryzoni zaledwie tysiąc kcal. Roczna konsumpcja pokarmu przez gryzonie przekracza 76 tys. kcal/ha, co odpowiada ponad $20 \mathrm{~kg}$ siana zjedzonego z każdego hektara połoniny. Wpływ gryzoni na roślinność połonin jest jednak bardzo znikomy, zużywają one zaledwie $1,03 \%$ z rocznej produkcji pierwotnej netto, którą oceniono na $7.400 .000 \mathrm{kcal} / \mathrm{ha}$. 